\title{
Review of Research on the Use of Audio-Visual Aids among Learners' English Language
}

\section{Charanjit Kaur Swaran Singh ${ }^{1}$, Harpreet Kaur Sarvinder Singh ${ }^{2}$, Tarsame Singh Masa Singh ${ }^{3}$, Eng Tek, Ong ${ }^{4}$, Melor Md Yunus ${ }^{5}$, Henita Rahmayanti ${ }^{6}$, Ilmi Zajuli Ichsan ${ }^{7}$}

\author{
${ }^{1,2}$ Faculty of Education and Communication, \\ ${ }^{1,2,4}$ Universiti Pendidikan Sultan Idris, Malaysia \\ ${ }^{3}$ Institute of Teacher Education, Tuanku Bainun Campus, Malaysia \\ ${ }^{5}$ Faculty of Education, Universiti Kebangsaan Malaysia, Malaysia \\ ${ }^{6}$ Department of Population and Environmental Education, Universitas Negeri Jakarta, Indonesia \\ ${ }^{7}$ Department of Population and Environmental Education, Universitas Negeri Jakarta, Indonesia \\ ${ }^{1}$ charanjit@fbk.upsi.edu.my
}

Article History: Received: 10 November 2020; Revised: 12 January 2021; Accepted: 27 January 2021; Published online: 05 April 2021

\begin{abstract}
This paper reviews the literature on the use of audio-visual to improve lower proficiency learners' English Language. Audio-visual aids have been very beneficial to make learning interesting among the English as a second language (ESL) because it facilitates learning. Teachers have to be innovative in their pedagogy approach to make language teaching effective. Today, teachers are no longer dependent on traditional method of teaching instead they have adapted different techniques to teach language. Past studies have reported that teachers opted to use audio-visual because students showed less interest towards English language, students view English language as subject to fulfil the examination requirement, students' displayed reluctance to speak due to their fear to make mistakes in pronunciation and other. Hence, this paper further analyses the need to investigate the issues that are related on the usage of audio-visual aids to the teaching of English language which needs immediate attention.
\end{abstract}

Keywords: Audio-visual aids; English Language, ESL learners

\section{Introduction}

English Language is a very important character in shaping Malaysian people's identity, particularly students, and the English Language has always played an important role in Malaysia's mission to become a developed country. To make it a success, technology has been implemented as one of the main factors that could help students learn the language more effectively. New technologies have been brought up into language learning with the advancement of technology. Nowadays teachers use various types of audio visual aids, such as YouTube, to promote the learning process for students to obtain the target language. This latest technique tends to be one of the best ways to draw research on improving lower proficiency learners speaking skills in the English Language.

As teachers, in our teaching and learning processes we need to be innovative because the students learn better with the right approach. Audio-visual aids in English Language Classroom today are the best way to teach students, and this is the research I have been working on and studying whether audio-visual aids really allows students with lower proficiency level develop their speaking skills. As we all know, there are four main skills namely speaking, reading, writing, and listening. Speaking skills, however, is the most important factor for students to learn and develop because in the near future they have to face everything in English and without English. Besides, to help students complete their language learning, teachers can use a range of teaching strategies and methods.

\section{Literature Review}

\section{Definition of audio-visual aids}

Audio visual aids are teaching methods used during sound and visual communication of messages more effectively. Teaching aids encourage students ' interest and help the teachers to easily understand the process. Knowingly or unknowingly, audio visual aims to accommodate the academic process in the classroom. Audiovisual aids can be categorized in three different categories such the following: audio aids, video aids and audiovisual aids.

The audio aids: - 
An audio aids is something that gives real life-like experience of a textbook or something that is written but in a form of "something that can be heard". Learners gain knowledge by using their hearing senses. For example, cassettes, songs, linguaphone and tape-recorders.

The visual aids: -

A visual aid on the other hand is a powerful tool to enhance the impact of the lesson taught. It helps learners to visualize the lesson effectively as the teacher "shows them to the students". For example, picture, graphs, transparency slides, flashcards and printed materials.

The audio-visual aids (AV): -

An audio-visual aid provides fun learning experiences, interactive lessons, and allows the teaching and learning process to take place effectively. This is because the both audio-visual aids are important part of a lesson as it is vital to have lessons where learners can "see and hear" at the same time concurrently. For example, videos, 3D-shows, virtual classroom, and film projector.

\section{Audio-visual aids in teaching and learning process}

According to Hassan (2012), audio-visual aids has been used in the Malaysian Education since 1950s as a method to deliver lessons in a much more creative and innovative manner. However, many teachers still preferred using the traditional method in their lessons, but then the $21^{\text {st }}$ Century Learning was introduced and teachers were asked to implement it in their daily lessons.

Audio-visual aids have proven to be one of the easiest ways to communicate with students these days and also it helps the teaching learning process as it allows students to understand the lesson effectively. Audio-visual generally makes teaching and learning impactful and empower and, notably, establish a language environment for the students (Daniel, 2013). Audio-visual guidance tends to make teaching and learning effective, since it provides a positive learning environment for all students and generates involvement and opportunity (Daniel, 2013).Besides that, according to Bhatti (2019), teachers should definitely use more audio-visual aids to improve the speaking skills of the learners as activities done using audio-visual aids may help in providing free and spontaneous practice of language with the help of audio-visual aids. They are indeed prone to watching shows and listening to music in their first language, either in their homes or outside. Learners use the first language of their discourse while referencing with their mates. They may not have enough prospects to use English when speaking with people around them. Yet when they're in classes they feel nervous about using the language because they'd feel ashamed if they made a mistake in pronouncing terms they don't learn. Even the teachers' lessons don't encourage them enough to be enthusiastic about knowing foreign language.

According to Richter and Nel (2017), the use of audio-visual aids in teaching has been promulgated in a number of studies as useful tools to explain challenging concepts and ideas in an approachable and collaborative manner as well as to foster procedural demonstration. Teacher at times face a lot of issues in explaining lessons to students especially those with poor proficiency level hence using the audio-visual aids can help bot just the teachers but also the learners to understand the lesson taught effectively.

Shah and Khan (2015) shared that using audio-visual aids reinforces that imagery and facts perceived onscreen generated a distinguishable educational environment from textual content which was beneficial to development of creative thinking. The Malaysian education system has turn to " The 21 st Century" teaching and learning style where audio-visual are taken very seriously in recent times by conducting lessons using interesting applications regardless online or offline. Ismail et al., (2017) believes that although the education system in Malaysia progresses with the development and progress in audio visual the research in this area in the recent years has been limited particularly in the rural areas. He further adds, teachers often faced challenges such as insufficient resources and poor internet connectivity while constantly trying to embed audio-visual materials into teaching. Teachers constantly faced difficulties such as lack of resources and restricted internet access while constantly trying to inject audio-visual materials into teaching.

Ismail et al. (2017) and Cheung (2017) further explain the interest of teaching and learning process was less impacted by the convenience of bearing in mind the contents which were taught extra. The encouragement to stimulate students ' learning interest is adequate, as also shown by the study of correlation, stressed that speaking skills tend to have a far-reaching focus or an elusive entity whereby pupils as other skills tend to be difficult to attain. In a normal classroom setting, students are not motivated with traditional methods of teaching and learning, hence audio-visual aids will definitely bring up the joy in the lesson. The students in the experimental 
groups, especially when audio-visual aids are played, showed significantly better attention span compared to students in the control group.

As example, researchers like Ismail, Othman, Amiruddin and Ariffin (2017) used animated videos for engineering Drawing delivery among students at Malaysia's Vocational College and recognized a tremendous potential for assistance for meaningful analysis for students, thereby educational quality increase. Moreover, audio-visual supports in language learning and teaching received significantly more attention than in science teaching (Khan, Shah, Farid \& Shah 2016).

A motivated English teacher with a new viewpoint is desirable for students as he or she usually includes them by using set of linguistic learning activities. Latest innovative innovation enables teachers construct a productive and conducive atmosphere to learning. Anil (2015) stressed that audio visual aids are being used to develop students' critical thinking. Multimedia education could also be used to teach pronunciation, accent, vocabulary, reading, writing, listening and voice. Current technological developments have created new possibilities for development of the virtual audio-visual aid in the English learning classroom. The growth, evaluation and creative skills of students can also be improved by showing illustrations, stimulated by speeches by great people. The students are more interested about using the range of words, which suggests the resourceful English teacher with various approaches.

Halwani (2017) explored the use of audio-visual aids helps students master the content and develop speaking skills and become engaged with no apprehension, trouble in the classroom because of shyness. It is obvious that language speakers who really aren't native speakers are much more highly reliant on audio visual aids to assist their learning, and it is undoubtedly a transparent way to empower students to produces high level of speaking proficiency.

Roblyer and Doering (2010)mention that the recent trends in technology has allowed a wider variety of tools and applications that can be used for teaching and learning. Audio-visual aids have clearly made its mark by creating many new applications not just for the students but also for the use of the teachers, such as YouTube, Google Classroom, Zoom App, and many other applications. Both students and teachers have been able to access many of these applications easily and also use them in achieving the $21^{\text {st }}$ Century Learning effectively as it helps to contextualisation the learning process.

Yang, Chen and Jeng (2009) mentioned that the second or foreign language learners must be provided with awareness of the language, including the use of grammar, vocabulary and the usage of sentence structure. It is vital for the language users to know how to use it and using the audio-visual aids learners are able to experience the usage of the language better as it will allows leaners to pick and understand the language especially those learners that belong to the lower proficiency group. Besides that, it is also believed that the audio-visual aids are able to provide support to the learners in developing the concept and improve the level of proficiency further.

Spratt, Pulverness, and William (2011) stated that speaking is a productive skill, like writing. It is also said to be an intricate process as it acquires a lot more than just communication. It also involves proper communication between people because it is quite evident that when people communicate, they express themselves in many different ways hence the use of audio-visual aids helps learners to improve their communication skills as they express themselves while interacting with people around them. Teaching and learning process can become a fun and educational process if teachers use the facility of the audio- visual aids. This will not just make the lesson fun and interactive but it will evidently improve the speaking skills of the learners especially those learners that poses low speaking proficiency skills. Moreover, the usage of audio-visual aids will develop the learners' ability to speak the language much more effectively with appropriate sentence structure and grammar.

Supiyati (2011) asserted that one of the appropriate interventions in order to enhance students' speech skills is the virtual implementation of audio-visual aids. She further adds, students become more excited when there is the usage of audio-visual aids in their daily lessons in the classroom and it is a proven fact that teaching and learning have been enjoyed by not just students but also teachers while teaching them. Lessons that are conducted with audio-visual aids provides a chance for many students to speak through the lesson as the teacher facilitate and such lessons helps in improving their proficiency level in the language. . This review study aims to provide information on the use of audio-visual aids in improving the speaking skills of learners with low proficiency level. 


\section{Methodology}

This paper seeks to present information on the issues related to the use of audio-visual aids based on the literature review of previous research of other scholars. The results were analysed and presented in the table using document analysis as shown below:

Table 1. Summary of Previous Research

\begin{tabular}{|c|c|c|c|c|}
\hline No & Author(s)/Article/ Year & Types of study & Research design & Findings \\
\hline 1. & $\begin{array}{l}\text { Ashaver, D., \& Igyuve, S. } \\
\text { M. (2013). The Use of } \\
\text { Audio-Visual Materials in } \\
\text { the Teaching and Learning } \\
\text { Processes in Colleges of } \\
\text { Education in Benue State- } \\
\text { Nigeria. }\end{array}$ & Qualitative & Survey & $\begin{array}{l}\text { The researchers were able } \\
\text { to conclude that there were } \\
\text { inadequate teaching aids } \\
\text { and the audio-visual aids } \\
\text { were rarely used by the } \\
\text { educators. }\end{array}$ \\
\hline 2. & $\begin{array}{l}\text { Izwan, A. K., \& Abdul, R. } \\
\text { N. Lina. (2010). A Study on } \\
\text { Second Language Speaking } \\
\text { Anxiety Among UTM } \\
\text { Students. }\end{array}$ & Qualitative & Survey & $\begin{array}{l}\text { The researchers' findings } \\
\text { clearly showed, there are } \\
\text { three factors of second } \\
\text { language anxiety. They are } \\
\text { Communication } \\
\text { Apprehension, Fear of } \\
\text { Negative Evaluation and } \\
\text { General Feeling of } \\
\text { Anxiety. }\end{array}$ \\
\hline 3. & $\begin{array}{l}\text { Hosni, S. (2014). Speaking } \\
\text { Difficulties Encountered by } \\
\text { Young EFL Learners. }\end{array}$ & Qualitative & Case study & $\begin{array}{l}\text { This study revealed that } \\
\text { the main speaking } \\
\text { difficulties encountered by } \\
\text { students are linguistic } \\
\text { difficulties, mother tongue } \\
\text { use, and inhibition. }\end{array}$ \\
\hline 4. & $\begin{array}{l}\text { Allou, A. (2013). The Effect } \\
\text { of Audio-visual Aids in } \\
\text { Teaching Speaking Skill } \\
\text { among EFL Learners. }\end{array}$ & Qualitative & Questionnaire & $\begin{array}{l}\text { The researcher believe that } \\
\text { if we use audio-visual } \\
\text { materials, the students' } \\
\text { speaking abilities can be } \\
\text { improved. }\end{array}$ \\
\hline 5. & $\begin{array}{l}\text { Al-Sabai, D. (2004). } \\
\text { Promoting Oral Fluency of } \\
\text { Second Language Learners. }\end{array}$ & Qualitative & Case Study & $\begin{array}{l}\text { The study showed there is } \\
\text { a mismatch between } \\
\text { teacher and students } \\
\text { perceptions on promoting } \\
\text { oral fluency of the L2. }\end{array}$ \\
\hline 6. & $\begin{array}{l}\text { Bhatti, M. S., Mukhtar, R., } \\
\text { Arshad, A., \& Jabeen, Z. } \\
\text { (2019). Investigating } \\
\text { Teaching Speaking Skills } \\
\text { Through Audio-visual Aids } \\
\text { for ESL Learners. }\end{array}$ & Qualitative & Survey & $\begin{array}{l}\text { The study concluded that if } \\
\text { there are enough resources } \\
\text { of audio-visual aids } \\
\text { available, it can definitely } \\
\text { help the teaching learning } \\
\text { process and further } \\
\text { improve students speaking } \\
\text { skills. }\end{array}$ \\
\hline 7. & $\begin{array}{l}\text { Che Musa, N., Lie, K. } \\
\text { Yew., \& Azman, H. (2012). } \\
\text { Exploring English } \\
\text { Language Learning and } \\
\text { Teaching in Malaysia. }\end{array}$ & Qualitative & Case Study & $\begin{array}{l}\text { The paper reviewed:- } \\
\text { * "Bahasa Malaysia" has a } \\
\text { strong influence over the } \\
\text { English language in } \\
\text { Malaysia } \\
\text { *an improved English } \\
\text { language curriculum } \\
\text { encourages students to } \\
\text { become independent and } \\
\text { allows students to think } \\
\text { critically } \\
* \text { The pedagogical }\end{array}$ \\
\hline
\end{tabular}




\begin{tabular}{|c|c|c|c|c|}
\hline & & & & $\begin{array}{l}\text { practices need to be } \\
\text { investigated by future } \\
\text { researchers in order to } \\
\text { develop teachers' and } \\
\text { students' knowledge } \\
\text { further. }\end{array}$ \\
\hline 8. & $\begin{array}{l}\text { Daniel, J. (2013). Audio- } \\
\text { Visual Aids in Teaching of } \\
\text { English. }\end{array}$ & Qualitative & Case Study & $\begin{array}{l}\text { Researcher identified } \\
\text { benefits, advantages and } \\
\text { principles of using audio- } \\
\text { visual aids effectively. }\end{array}$ \\
\hline 9. & $\begin{array}{l}\text { Singh, C. K.S., Samad, A. } \\
\text { A., Hussin, H., \& Sulaiman, } \\
\text { T. (2015). } \\
\text { Developing a Portfolio } \\
\text { Assessment Model for the } \\
\text { Teaching and Learning of } \\
\text { English in Malaysian L2 } \\
\text { Classroom. }\end{array}$ & Qualitative & Case Study & $\begin{array}{l}\text { The researchers were able } \\
\text { to conclude that the use of } \\
\text { "Portfolio Assessment } \\
\text { Model" has many } \\
\text { advantages in the teaching } \\
\text { and learning of the English } \\
\text { language in the Malaysian } \\
\text { L2 classroom. }\end{array}$ \\
\hline 10. & $\begin{array}{l}\text { Eyesus, G. (2014). The } \\
\text { Exploring the Causes of } \\
\text { Students' Reluctance in } \\
\text { English Speaking } \\
\text { Classroom. }\end{array}$ & Qualitative & Case Study & $\begin{array}{l}\text { The researcher identified } \\
\text { some factors causing } \\
\text { reluctance in students in } \\
\text { English language } \\
\text { classroom. }\end{array}$ \\
\hline 11. & $\begin{array}{l}\text { Hassan, F., \&Selamat, N. F. } \\
(2002) \text {. Why Aren't Student } \\
\text { Proficient in ESL The } \\
\text { Teachers' Perspective. }\end{array}$ & Qualitative & Survey & $\begin{array}{l}\text { In this study, the } \\
\text { researcher found the } \\
\text { "listening" and "speaking" } \\
\text { skills are much neglected } \\
\text { however, the "writing" and } \\
\text { "reading" is given more } \\
\text { importance. }\end{array}$ \\
\hline 12. & $\begin{array}{l}\text { Ismail, M.E., Irwan } \\
\text { Mahazir, I., Othman, H., } \\
\text { Amiruddin, M.H., \& } \\
\text { Ariffin, A. (2017). The use } \\
\text { of animation video in } \\
\text { teaching to enhance the } \\
\text { imagination and } \\
\text { visualization of student in } \\
\text { engineering drawing. }\end{array}$ & Quantitative & Survey & $\begin{array}{l}\text { This study concluded, that } \\
\text { video animation is able to } \\
\text { increase students } \\
\text { understanding effectively, } \\
\text { enhancing students' } \\
\text { imagination and } \\
\text { visualization too. }\end{array}$ \\
\hline 13. & $\begin{array}{l}\text { Idris. A. (2015). The Effects } \\
\text { of Audio-Visual Materials } \\
\text { in the Teaching and } \\
\text { Learning of the Speaking } \\
\text { Skill in Junior Secondary } \\
\text { Schools. }\end{array}$ & Qualitative & Case Study & $\begin{array}{l}\text { The researcher's finding } \\
\text { resulted that audio-visual } \\
\text { aids materials play a vital } \\
\text { role in learner's oral skills. }\end{array}$ \\
\hline 14. & $\begin{array}{l}\text { Jarosievitz, B. (2015). The } \\
\text { impact of ICT and } \\
\text { multimedia used to flip the } \\
\text { classroom (Physics lectures) } \\
\text { via } \\
\text { Smart phones and tablets. }\end{array}$ & Qualitative & Case study & $\begin{array}{l}\text { The researcher discovered } \\
\text { that traditional methods } \\
\text { should be changed as it } \\
\text { does not encourage the } \\
\text { students nor change their } \\
\text { behaviour. }\end{array}$ \\
\hline 15. & $\begin{array}{l}\text { Shah, N. S. K., \& Shah, N. } \\
\text { F. S. (2016). Perception of } \\
\text { High Schools Principals' } \\
\text { About The } \\
\text { Weak English-Speaking } \\
\text { Skill of Teachers In District } \\
\text { Peshawar. }\end{array}$ & Qualitative & $\begin{array}{l}\text { Quasi-experiment } \\
\text { with questionnaire } \\
\text { survey }\end{array}$ & $\begin{array}{l}\text { This paper resulted that } \\
\text { teachers should be aware } \\
\text { of the significance of } \\
\text { English-speaking skills } \\
\text { however, they lack in } \\
\text { confidence and their } \\
\text { culture constraints too. }\end{array}$ \\
\hline
\end{tabular}


Charanjit Kaur Swaran Singh, Harpreet Kaur Sarvinder Singh, Tarsame Singh Masa Singh, Eng Tek, Ong, Melor Md Yunus, Henita Rahmayanti, Ilmi Zajuli Ichsan

\begin{tabular}{|c|c|c|c|c|}
\hline 16. & $\begin{array}{l}\text { Knutson, S. (2003). } \\
\text { Experiential Learning in } \\
\text { Second Language } \\
\text { Classrooms. }\end{array}$ & Qualitative & Case Study & $\begin{array}{l}\text { The paper was aimed to } \\
\text { identify task-based } \\
\text { learning. }\end{array}$ \\
\hline 17. & $\begin{array}{l}\text { Meriem, M. (2012). } \\
\text { The Role of Audio-Visual } \\
\text { Aids in Enhancing EFL } \\
\text { Students 'Speaking Skill } \\
\text { Case Study First Year LMD } \\
\text { Students of English at } \\
\text { Biskra University. }\end{array}$ & Qualitative & $\begin{array}{l}\text { Descriptive } \\
\text { method }\end{array}$ & $\begin{array}{l}\text { The researcher's finding } \\
\text { resulted that the usage of } \\
\text { audio-visual aids can } \\
\text { improve and enhance the } \\
\text { speaking skills of the } \\
\text { students effectively. }\end{array}$ \\
\hline 18. & $\begin{array}{l}\text { Tuan, N. G., \& Mai, T. N. } \\
\text { (2015). Factors Affecting } \\
\text { Students' Speaking } \\
\text { Performance at Le } \\
\text { Thanh Hien High School. }\end{array}$ & Qualitative & $\begin{array}{l}\text { Case Study } \\
\text { Questionnaire }\end{array}$ & $\begin{array}{l}\text { The researchers concluded } \\
\text { that, } \\
\text { students lack in } \\
\text { motivation, students are } \\
\text { reluctant to speak the } \\
\text { language, and the L1 has a } \\
\text { vital effect on the L2. }\end{array}$ \\
\hline 19. & $\begin{array}{l}\text { Paakki, H. (2013). } \\
\text { Difficulties in Speaking } \\
\text { English and Perceptions of } \\
\text { Accents - A Comparative } \\
\text { Study of Finnish and } \\
\text { Japanese Adult } \\
\text { Learners of English. }\end{array}$ & Quantitative & Interview & $\begin{array}{l}\text { The researcher concluded } \\
\text { that Finnish adults and } \\
\text { Japanese adults found } \\
\text { English language complex } \\
\text { and difficult and } \\
\text { challenging. }\end{array}$ \\
\hline
\end{tabular}

Ashaver and Igyuve (2013) conducted a research namely the use of audio-visual materials in the teaching and learning processes in colleges of education in benue state-Nigeria in the year 2013 which was aimed in finding out the use of audio-visual aids in the teaching learning process in a college of education in Benue StateNigeria. In order to conduct this research, the researchers used 13 questions which were 6 research questions and 2 sets of questionnaires that were distributed to the students and lecturers equally. The findings of the research were that there is an inadequate use of audio-visual aids used in the college, however lecturers did not often use the audio-visual aids in the teaching learning process. Besides that, there were also many issues on the lack of infrastructure support, human activities are another major throwback to the usage of audio-visual aids and the audio-visual resources prepared by the librarian isn't impressive either. The positive thing that the researcher could conclude in from this paper was that lecturers were quick in improvising the materials during the lesson.

Abdullah, Izwan and Abdul Rahman (2010) carried out a study to analyse the three levels of anxiety namely the "Communication Apprehension" anxiety, "Fear of Negative Evaluation" anxiety and "General Feeling of Anxiety". This research proved that the findings of the study conducted by McCroskey (1997) that mainly people face communication apprehension while speaking in a formal setting. Students were rated according to their "SPM English Language Results" and "MUET". Most of the students scored Band 2 or Band 3 in their MUET which clearly showed that students faced issues in speaking the L1 however they were much more confident while communicating in their L2 with their friends that belonged to the same level of proficiency.

Hosni (2014) conducted a research on speaking difficulties encountered by young EFL learners. The reasons were clear after the research was conducted as it showed that those grade 5 students were facing this difficulty due to linguistic difficulties, the use of L1 and inhibition. Besides that, students also were having difficulties in formatting proper sentences which made them shift to their mother tongue often and students also were quite uncomfortable to speak the L2 in front of their peers and students shun away from the language. However, in the teacher's opinion, they are unable to provide much as there is constant time constraint from their very own end which results in more writing and reading instead of speaking activities in the class. To mend this situation, the teacher has fairly tried to emphasize some activities in their lessons such as targeting teaching grammar rules and vocabulary items.

Allou (2013) reported that audio-visual aids were an effective way to improve one's speaking skills as it provides a full interpretation of a lesson. The researcher used a questionnaire to prove his findings and help us understand the importance of audio-visual aids and the end results of the research proved that audio-visual aids do improve the speaking abilities of a student. The researcher also provided some suggestions and recommendations on how can teachers improve the speaking skills of a student using the audio-visual aids. 
Sabai (2014) study revealed that there is a mismatch between teacher and students' perceptions on promoting oral fluency of the L2. This paper was based on many case studies that proved that L2 has a stronger effect on the students than the L1.

Bhatti, Mukhtar, Arshad, and Jabeen (2019) identified the level of speaking skills by using appropriate audiovisual aids. In his findings and discussion, the researcher clearly stated that audio-visual aids can actually improve one's speaking skills as it allows students to speak English. Audio-visual aids can also encourage students in developing their English proficiency if teacher changes some teaching techniques. However, the researcher also found out that teachers were unable to make much improvement due to two factors, unavailability of lab appliances and lack of dedicated teachers. It is quite evident that experienced and good source of appliances will definitely make a difference in improving students proficiency level by using the audio-visual aids.

Musa, Lie and Azman (2012) reported that the Bahasa Malaysia has a strong influence on the English language which has resulted in the literacy of the language. Besides that, the researchers also believe that there should be an improved curriculum with much more learning in a real-life like experience can create a learner that can proficient in the language. The area of education is still focused on literacy and language learning. Language is used as a learning and knowledge transmission medium. It is very important for language educators and policy makers to study carefully how language learning is theorized and modified to promote better English learning among our learners. In this regard it is important. The need is instantaneous.

Daniel (0213) explained how audio-visual aids can effectively serve in the purpose of teaching learning process in the classroom. That is why it is difficult for teachers to teach English. In language teaching, the main aim of audio-visual aids is to enable the teacher to teach efficiently and attractively. The teacher uses the direct method in the teaching of English. Thus, by means of audio-visual aids, the teacher must give the students a clear idea. Teaching instruments can only be used to complement oral and written class work. These aids alone are favoured and inspire students to think and do more. Only after careful preparation can a teacher use an instructional service so that the aid can be used exactly where it suits best in the context of education.

Singh, Samad, Hussin and Sulaiman (2015) identified the techniques used by ESL teachers in portfolio implementation as evaluation tools. The techniques used by the teachers in the classroom during the evaluation process allowed the researchers to create an effective portfolio evaluation model. This researchers analysed the procedures used by teachers in the L 2 classroom as a reference to effective teaching and learning process. There were nine high school teachers involved from Malaysia. The approaches which served as a guideline to the English teachers in their teaching and learning in class were investigated during semi-structured interviews, classroom observations and individual teacher portfolios.

Eyesus (2014) concluded majority of the students still have problems in their language proficiency. The two problem areas were identified by the lack of vocabulary and the failure to master the structures of English sentences. Therefore, activities to improve the vocabulary of students are highly encouraged. Besides that, developing the language skills of the students can further be done as the language teachers target on the language grammar. It is logical to conclude that the majority of students want to learn good English and are prepared to interact in oral English classrooms with others. For different reasons like lack of practice, however, many students were reluctant to answer the teacher and choose to keep quiet until they were singled out to answer questions. This is clearly due to their poor English skills, their lack of trust, anxiety, cultural beliefs, personality and fear of being embarrassed.

Hassan and Selamat (2002) discussed teacher's perceptions on KBSM student's proficiency level and targets how teachers practice their teaching process in their classroom. The results were collected from 58 KBSM teachers from central region. In this paper it was also very evident that speaking skill was not given much importance by the teachers in their teaching learning lessons. It was a huge mixture of lack of attention and student's lack of competence in the language have made students to hinder themselves from the language. The KBSM syllabus has proven to be effective in the reading and writing skills however neglects the writing and specially speaking skills. Audio-visual aids can definitely help in developing the speaking skills that many teachers are unable to. It is important that we are able to utilize the power of audio-visual aids in their daily teaching learning process.

Ismail, Irwan Mahazir, Othman, Amiruddin, \& Ariffin (2017) reported findings help to shape a multimedia portion of aids appropriate for improving the quality of learning content for engineering drawing. Quality of 
education and skills of students are commonly associated with teacher and student teaching methods themselves. Therefore, teachers are expected to use teaching materials such as audio-visual aids to increase students level of excellence. Audio-visual aids can help both teachers and students in achieving the excellence level needed.

Jarosievitz (2015) mentioned the importance of embracing the advantage of ICT, multimedia (text, pictures, animation, sound, video and interactivity) and new devices and their implementation from universities or even high schools with sufficient knowledge and relevant understand exactly-how in physics. All activities must be measured during the implementation by the teacher and a method of cooperation with the ICT and multimedia should be combined. Its use in physics lectures will eventually have a positive impact and change in the student's behaviour.

Shah, Farid and Shah (2016) conducted a study to identify the obstacles faced by the teachers in Government High School in spoken English in the district of Peshwar. The researchers proposed few recommendations which were related to the advantages of audio-visual aids which were provided by the department of education. In many government schools in the district it was evident that even the principals agreed that English competency is important for high school students. The teachers' spoken English skills cannot be accomplished by which native language they use during the teaching and learning. There is no such material in the educational curriculum of which they can be highlighted. In schools, audio-visual aids are not available hence it is tough for teachers in improving their students' spoken skills. This clearly proves that audio-visual aids are vital in todays' world in order to help students especially when English is their L2.

Knutson (2013) build a theoretical framework to incorporate conceptual processes in the second language classroom by conducting experimental English as a second language teacher approaches and by examining second-language studies based on the experimental methodology. In the initial stage of the research, the researcher has successfully identified between real life and imagination life, and this can be done best with audio-visual aids.

Meriem (2012) carried out a study to examine the consequences of the teaching aids on the skills of first year learners in English language at the University of Biskra in speaking and communicating. The main aim of the research was to demonstrate the value of using EFL students for audio-visual support. The fundamental hypothesis of this research is that teachers will build the speaking skills of students with the use of audio-visual aids. The evaluation of the questionnaires showed that these teaching methods are an effective tool for improving speaking ability, both for teachers and students. Singh et al. (2020) divulged that it is very crucial to assess students' learning to look at the attainment of learning outcomes of the subjects taught.

Tuan and Mai (2015) conducted a study to help teachers and students at the Le Thanh Hien High School in improving their performance in speaking classes. Through their research, they discovered that students from the Le Thanh Hien High School have low speaking proficiency in their English Language. There are various factors that influence the low proficiency level in the students from this school namely consider taking time to complete, pressurize for positive results, support listeners, encourage communicate, motivation, fear as well as the ability to listen.

Musa, Lie \& Azman (2012) in their study identified factors that contribute in Malaysian students to medium or poor level of English literacy. Besides that, their study discussed some of the relevant issues of English learning in this country and competing oral presentations. It reflects the diverse conceptualization of the teaching of English in our schools, raising important questions for Malaysian learners and society in general regarding the positions of English literacy. It is evident that audio-visual aids can improve students' proficiency level.

Paakki (2013) reported problem to be studied in order to fix the problem, not only in develop knowledge of the language and written skills but also to teach oral English. The objectives of this research were to find if adult English language learners have English speaking problems, and if so, what kinds of issues and why. The participation in English language media has also increased, particularly in Finland, and as such has been an additional one. The paper also aimed at exploring if this has produced difficulty for English studies and what accent should be imposed on the learner.

\section{Discussion}

Reviews made based on the previous studies pertaining to audio-visual aids showed that many studies adopted qualitative specifically case studies research design to collect data. It was also apparent that samples selection in most of the studies were relatively not big and indicate low precision. It is proposed in this study that 
researchers should include and conduct studies with larger sample size and longer treatment duration for the initiated studies in the future. It was also found that audio-visual aids were used extensively in terms of language acquisition namely writing skills, oral skills and vocabulary. Audio-visual aids have been used across other domains or disciplines like engineering, physics, assessment, in teaching and learning process in some of the selected colleges. Singh et al. (2020) divulged that audio-visual aids can be facilitated through the infusion of cooperative learning approach as it would boost students' confidence and motivation towards speaking skills. Singh et al. (2020) reported that songs can also enhance and improve learners' speaking skills. Audio-visual aids have been viewed to be influential in terms of engaging learners in learning and also enhance retention. Teachers use audio-visual aids as an additional learning materials or information to facilitate students learning. Students when they are taught using visual aids, they would be able to use those images to relate or connect to the subject matter that is being discussed. Not only, Singh et al. (2019) and Ichsan et al. (2020) divulged that audio-visual aids have benefits as it is able to increase students' higher order thinking skills as to infer, predict, evaluate and others.

\section{Conclusion}

The use of audio-visual aids in English Language classes provides an understanding of difficult concepts. In addition, there really is no encouragement for learners in traditional teaching learning methods and teaching aids stimulate the curiosity of learners and facilitate learning to explain learning concepts easily. In fact, the preference of teaching aids depends mainly on what and how to teach and who / where the learners are. It is recommended that appropriate teaching aids establish the language skills of EFL learners and improve the efficient skills of learners. This means that teaching aids master the ability of learners to express their own opinions effectively.

\section{References}

1. Ashaver, D., \& Igyuve, S. M. (2013). The Use of Audio-Visual Materials in the Teaching and Learning Processes in Colleges of Education in Benue State-Nigeria. Journal of Research \& Method in Education, 1(6), 44-55.

2. Abdullah, K. I., \& Ab Rahman, N. L. (2010). A Study on Second Language Speaking Anxiety among UTM Students. Universiti Teknologi Malaysia. A report submitted in partial fulfilment of the requirements for the award of the degree of Bachelor of Science with Education (TESL).

3. Al Hosni, S. (2014). Speaking Difficulties Encountered by Young EFL Learners. International Journal on Studies in English Language and Literature, 22-30.

4. Allou, A. (2013). The Effect of Audio-visual Aids in Teaching Speaking Skill among EFL Learners.

5. Al-Sibai, D. (2004). Promoting oral fluency of second language learners: Educational linguistics. Association for Experiential Education. (2011). Retrieved February 28, 2017, from Association for Experiential Education: http://www.aee.org/

6. Bhatti, M. S., Mukhtar, R., Arshad, A., \& Jabeen, Z. (2019). Investigating Teaching Speaking Skills Through Av Aids for ESL Learners. International E-Journal of Advances in Education, 5(13), 75-82.

7. Che Musa, N., Koo, Y., \& Azman, H. (2012). Exploring English Language Learning and Teaching in Malaysia. GEMA Online Journal of Language Studies, 35-51.

8. Daniel, J. (2013). Audio-Visual Aids in Teaching of English. International Journal of Innovative Research in Science, Engineering and Technology, 2(8), 3811-3814.

9. Gebre-eyesus, A. (2014). Exploring the Causes of Students' Reluctance in English Speaking Classroom: The Case of Gode Secondary and Preparatory School.

10. Hassan, F., \& Selamat, N. F. (2002). Why Aren't Students Proficient in ESL: The Teachers' Perspective. The English Teacher. Retrieved fromhttp://www.melta.org.my/ET/2002/wp10.htm

11. Ismail, M. E., Othman, H., Amiruddin, M. H., \& Ariffin, A. (2017, May). The use of animation video in teaching to enhance the imagination and visualization of student in engineering drawing. IOP Conference Series: Materials Science and Engineering, 203(2), 12-23

12. Idris, A. (2015). The Effects of Audio-Visual Materials in the Teaching and Learning of the Speaking Skill in Junior Secondary Schools. International Journal of Social Science and Humanities Research, 3(3), 50-58.

13. Ichsan, I. A., Rahmayanti, H., Purwanto, A., Sigit, D. V., Singh, C. K. S., \& Babu, R. U. M. (2020). HOTS-AEP-COVID-19: Students Knowledge and Digital Worksheet of ILMIZI Environmental Learning Model. International Journal of Advanced Science and Technology, 29(6), pp. 5231 - 5241.

14. Jarosievitz, B. (2015). The impact of ICT and multimedia used to flip the classroom (Physics lectures) via smart phones and tablets. In L. J. Thomas, R. Girwidz (Eds.), Proceedings of the 20th International Conference on Multimedia in Physics Teaching and Learning (pp. 357-363). Germany: LMU Munich. 
15. Khan, N., Shah, K., Farid, N., \& Shah, S. (2016). Perception of high schools' principals about the weak English-speaking skill of teachers in District Peshawar. Asian Journal of Social Sciences \& Humanities, 5(2), 29-36.

16. Knutson, \& Sonja. (2003). Experiential learning in second-language classrooms. 22.

17. Meriem, M. (2015). The Role of Audio-Visual Aids in Enhancing EFL Students' Speaking Skill (Doctoral dissertation, Biskra University).

18. Nguyen, H. T., \& Tran, N. M. (2015). Factors Affecting Students' Speaking Performance At Le Thanh Hien High School. Asian Journal of Educational Research, 3(2), 8-23.

19. Normazidah, C., Yew Lie, K., \& Hazita, A. (2012). Exploring English Language Learning and Teaching in Malaysia. 35-51.

20. Paakki, H. (2013). Difficulties in Speaking English and Perceptions of Accents A Comparative Study of Finnish and Japanese Adult Learners of English. Report submitted in partial fulfilment of the requirements for the award of the Master's degree.

21. Parveen, B. W. (2016). Use of Technology in Improving Speaking Skills. Veda's Journal of English language and Literature, 3(2), 121-124. Retrieved from http://www.joell.in

22. Sahin, M., Sule, S., \& Secer, Y. (2016, April 23). Challenges of using audio-visual aids as warm-up activity in teaching aviation English. Academic Journals, 11(8).

23. Swaran Singh, Charanjit, Kaur, Othman Lebar, Napisah Kepol, Rafiah Abdul Rahman \& Kurotol Aini Muhammad Mukhtar. (2017). An Observation of Classroom Assessment Practices Among Lecturers in Selected Malaysian Higher Learning Institutions. Malaysian Journal of Learning and Instruction. 14 (1), 23-61.

24. Singh, C. K. S., Samad, A. A., Hussin, H., \& Sulaiman, T. (2015). Developing a Portfolio Assessment Model for the Teaching and Learning of English in Malaysia L2 Classroom. English Language Teaching, 8(7), 164.

25. Singh, C. K. S., Ramachandran, A., Singh, T. S. M., Tek, O. E., Yunus, M. M., \& Mulyadi, D. (2020). The Use of Think Pair Share of Cooperative Learning to Improve Weak Students' Speaking Ability. International Journal of Psychosocial Rehabilitation. 24(5), 4008-4023.

26. Singh, C. K. S., \& Jeganmohan, S. (2020). A Review of Studies on action Songs among ESL Learners to Improve English. International Journal of Psychosocial Rehabilitation. 24(5), 2337-2344.

27. Singh, C. K. S., Singh, T. S. M., Ja'afar, H., Ong, E. T., Kaur, H., Mostafa, N. A., \& Yunus, M. M. (2020). Teaching Strategies to Develop Higher Order Thinking Skills in English Literature. International Journal of Innovation, Creativity and Change. 11(8), 211-231.

28. Shaimaa, A. (2006). The Effectiveness of a Task- Based Instruction program in Developing the English Language Speaking Skills of Secondary Stage Students. 1-254.

29. Shah, I., \& Khan, M. (2015). Impact of multimedia-aided teaching on students' academic achievement and attitude at elementary level. US-China Education Review, 5(5):349-360 